\title{
Strategi Pengembangan Industri Pariwisata (Studi Kasus Objek Wisata Pulau Rukui Kabupaten Aceh Tamiang)
}

\section{Tourism Industry Development Strategy (Case Study of Rukui Island Tourism Attraction, Aceh Tamiang Districts)}

\author{
Nurlina Nurlina ${ }^{1)}$, Yolanna Shofa Pratama ${ }^{2)}$, Puti Andiny ${ }^{3)}$ \\ ${ }^{1,2,3)}$ Fakultas Ekonomi, Universitas Samudra, Kota Langsa \\ e-mail korespondensi:putiandiny@unsam.ac.id
}

\begin{tabular}{|l|}
\hline Info Artikel \\
\hline Riwayat Artikel : \\
Diterima: 23 Januari 2021 \\
Disetujui: 28 Mei 2021 \\
Dipublikasikan: Januari 2022 \\
\hline Nomor DOI \\
10.33059/jseb.v13i1.3195 \\
Cara Mensitasi : \\
Nurlina, N., Pratama, Y. S., \& \\
Andiny, P. (2022). Strategi \\
pengembangan industri \\
pariwisata (Studi kasus objek \\
wisata Pulau Rukui Kabupaten \\
Aceh Tamiang). Jurnal \\
Samudra Ekonomi dan Bisnis, \\
13(1), 1-14. doi: \\
10.33059/jseb.v13i1.3195 \\
\end{tabular}

Abstrak
Studi ini bertujuan mengetahui strategi pengembangan industri pariwisata pada
Pulau Rukui Kabupaten Aceh Tamiang. Populasi yaitu pengunjung wisata,
BAPPEDA, serta Dinas Pariwisata, Pemuda dan Olahraga. Metode analisis
menggunakan SWOT (strengths, weaknesses, opportunities, and threats). Hasil
analisis menunjukkan faktor kekuatan utama adalah masyarakat mendukung
pemerintah dalam mengembangkan objek wisata; kelemahannya yaitu fasilitas
yang belum tersedia (toilet umum dan pondok bersantai); peluangnya yaitu objek
wisata ini mampu mendorong aktivitas ekonomi, menciptakan lapangan kerja
bagi masyarakat sekitar, banyaknya wisatawan yang ingin berkunjung ke Pulau
Rukui; serta, ancamannya adalah kurangnya kesadaran wisatawan untuk menjaga
kebersihan. Rekomendasi strategi adalah meningkatkan promosi melalui
berbagai media cetak maupun media elektronik; meningkatkan sarana, prasarana
dan infrastuktur penunjang; pemerintah dan investor swasta dapat bekerja sama
untuk menciptakan inovasi baru; serta, pemerintah bekerja sama dengan
masyarakat sekitar memberikan sosialisasi dan pembinaan sehingga
meningkatkan kualitas SDM.
meningkatkan kualitas SDM.

Kata Kunci: Pariwisata, Pulau Rukui, Analisis SWOT.

\begin{tabular}{|l|}
\hline Article Info \\
\hline Article History : \\
Received: 23 January 2021 \\
Accepted: 28 May 2021 \\
Published: January 2022 \\
\hline DOI Number: \\
10.33059/jseb.v13i1.3195 \\
How to cite : \\
Nurlina, N., Pratama, Y. S., \& \\
Andiny, P. (2022). Strategi \\
pengembangan industri \\
pariwisata (Studi kasus objek \\
wisata Pulau Rukui Kabupaten \\
Aceh Tamiang). Jurnal \\
Samudra Ekonomi dan Bisnis, \\
13(1), 1-14. doi: \\
10.33059/jseb.v13i1.3195
\end{tabular}

Abstract

The study aims to determine the tourism industry development strategy on Rukui Island of Aceh Tamiang Regency. The population is tourist visitors, Regional Development Planning Agency, and Tourism, Youth and Sport Office. The analysis method uses SWOT. The results show that the main strength factor is that the community supports the government in developing tourism objects; the weakness is that the facilities are not yet available (public toilets and lounging huts); the opportunity is that this tourist attraction is able to encourage economic activity, create jobs for the surrounding community, the number of tourists who want to visit Rukui Island; and, the threat is the lack of awareness of tourists to maintain cleanliness. The recommended strategies are to increase promotion through various print and electronic media; improve facilities, infrastructure and supporting infra-structure; government and private investors joint together to create new innovations; and, the government cooperates with the community to provide socialization and guidance so as to improve the quality of human resources.

Keywords: Tourism, Rukui Island, SWOT Analysis. 


\section{PENDAHULUAN}

Pariwisata adalah salah satu industri yang dapat memajukan pertumbuhan ekonomi suatu negara. Hal ini terlihat dari perannya mampu meningkatkan lapangan pekerjaan, pendapatan dan standar hidup serta memberi stimulus bagi pengembangan sektor lainnya. Wisata bahari dan pesisir merupakan wisata dengan perkembangan yang sangat cepat. Banyaknya potensi yang bisa dikembangkan, membuat objek wisata ini dapat dimunculkan sebagai produk unggulan daerah.

Kabupaten Aceh Tamiang memiliki 44 objek wisata, yaitu 31 wisata alam dan 13 wisata budaya (Badan Pusat Statistik, 2019). Salah satu wisata alam di wilayah tersebut yang banyak dikunjungi wisatawan akhirakhir ini adalah Pantai Pulau Rukui yang terletak di Kecamatan Banda Mulia. Namun sayangnya, trend tiga bulan terakhir di tahun 2019 (Tabel 1) menunjukkan ada penurunan kunjungan wisatawan ke objek wisata Pulau Rukui, dimana pada bulan Juni jumlah wisatawan sebanyak 890 orang dan di bulan September turun menjadi 123 orang.

Di sisi lain, Anggaran Pendapatan dan Belanja Daerah (APBD) Kabupaten Aceh Tamiang dalam lima tahun terakhir selalu mengalami defisit setiap tahunnya (Tabel 2). Adanya kondisi kekurangan anggaran ini mendorong pemerintah perlu melakukan pengembangan terhadap sektor objek wisata, khususnya Pulau Rukui ini agar mampu memberikan pemasukan bagi daerah tersebut.

Menurut Bahiyah et al. (2018) dalam penelitiannya tentang strategi pengembangan potensi pariwisata di Pantai Duta di wilayah Kabupaten Probolinggo, bahwa pemerintah harus bisa mengoptimalkan agar pengeluaran (belanja) yang dilakukannya tidak melebihi pendapatan yang diperoleh. Hal ini berarti pemerintah haruslah melakukan berbagai kebijakan untuk membiayai pengembangan sektor pariwisata, karena aspek terpenting dari kebijakan pariwisata akan menjadi kuantum insentif bagi pembangunan sektor pariwisata (Latuconsina et al., 2013). Alternatif strategi dapat melalui kebijakan investasi dan anggaran yang mencukupi, peningkatan pembiayaan swasta melalui kemitraan, koordinasi antara dengan pihak wirausaha pariwisata, dan komunikasi dengan masyarakat sekitar untuk dapat memanfaatkan potensi pariwisata sebagai sumber pendapatan (Latuconsina et al., 2013).

Tabel 1. Daftar Kunjungan Wisatawan ke Objek Wisata Pulau Rukui Tahun 2019

\begin{tabular}{ccc}
\hline Bulan & Jumlah Wisatawan (Orang) & Perkembangan $(\%)$ \\
\hline Januari & 613 & - \\
Februari & 218 & $-64,43$ \\
Maret & 270 & 23,85 \\
April & 340 & 25,92 \\
Mei & 457 & 34,41 \\
Juni & 890 & 94,74 \\
Juli & 186 & $-79,10$ \\
Agustus & 175 & $-5,91$ \\
September & 123 & $-29,71$ \\
\hline
\end{tabular}

Sumber: Dinas Pariwisata, Pemuda dan Olahraga Kabupaten Aceh Tamiang, 2020. 
Tabel 2. Anggaran Pendapatan dan Belanja Kabupaten Aceh Tamiang Tahun 2016-2020

\begin{tabular}{cccc}
\hline Tahun & Pendapatan (Miliar Rupiah) & Belanja (Miliar Rupiah) & Defisit (Miliar Rupiah) \\
\hline 2016 & 1.320 .426 .002 .016 & 1.361 .949 .982 .016 & 1.361 .949 .982 .016 \\
2017 & 1.241 .189 .072 .017 & 1.276 .189 .072 .017 & 1.276 .189 .072 .017 \\
2018 & 1.175 .611 .272 .018 & 1.199 .611 .272 .018 & 1.199 .611 .272 .018 \\
2019 & 1.315 .384 .382 .019 & 1.382 .766 .672 .019 & 1.382 .766 .672 .019 \\
2020 & 1.356 .109 .893 .020 & 1.368 .109 .893 .020 & 1.368 .109 .893 .020 \\
\hline
\end{tabular}

Sumber: Serambinews.com (diolah penulis), 2020.

Sebagai upaya untuk mewujudkan objek wisata Pulau Rukui sebagai daerah tujuan wisata, perlu adanya suatu strategi yang tepat, agar potensi yang dimiliki tidak menjadi siasia. Berdasarkan fenomena yang diuraikan, tujuan penelitian ini adalah mengidentifikasi strategi pengembangan industri pariwisata melalui kekuatan, kelemahan, peluang dan ancaman yang dimiliki objek wisata Pulau Rukui di Kabupaten Aceh Tamiang.

\section{Pengertian Pariwisata}

Pariwisata bisa didefinisikan sebagai perpindahan seseorang untuk sementara waktu, paling sedikit selama 24 jam dan paling lama selama 6 bulan, ke beberapa lokasi selain tempat bekerja dan tempat tinggal (Pradana, 2019). Orientasi dari pariwisata ini adalah kesehatan, kesenangan, berlibur, pendidikan dan relaksasi di lokasi tujuan wisata tersebut.

Sebagai sektor yang sangat diandalkan karena memiliki kontribusi besar terhadap pendapatan daerah, maka sektor pariwisata perlu ditata dan dikelola sedemikian rupa. Penanganan pariwisata yang didukung oleh jiwa wirausaha akan meningkatkan kunjungan wisatawan domestik dan mancanegara di wilayah itu. Meningkatnya jumlah kunjungan wisata tentu semakin banyak wisatawan yang membelanjakan uangnnya di daerah tersebut, sehingga mendatangkan pendapatan baik bagi pemerintah melalui retribusi dan pajak usaha maupun bagi masyarakat sekitar lokasi yang bersangkutan (Zebua, 2016).

\section{Siklus Hidup Pembangunan Pariwisata}

Berdasarkan pemikiran Butler, Utama (2017) menyatakan bahwa pembangunan dan pengembangan pariwisata secara umum mengikuti Tourist Area Life Cycle (TLC) atau siklus kehidupan pariwisata, sehingga dapat diketahui posisi pariwisata dan ditentukan jalur program pembangunannya. Konsep TLC dapat dijabarkan menjadi enam siklus seperti pada Gambar 1.

Siklus pertama adalah tahap penemuan. Pada tahap ini, potensi pariwisata baru berada pada proses identifikasi apakah memiliki potensi dan daya tarik untuk dikembangkan karena destinasi wisata ini didukung oleh keindahan alam yang alami, dan destinasi wisata ini telah dikunjungi oleh wisatawan walau dalam volume kecil.

Siklus kedua adalah tahap pelibatan. Pada tahap ini, penduduk lokal telah memiliki berbagai inisiatif untuk menyediakan layanan jasa bagi para wisatawan. Pemerintah dan masyarakat lokal telah mulai melakukan sosialisasi, namun masih terbatas pada harihari tertentu saja, seperti libur sekolah dimana terjadi kunjungan yang cukup besar. Pemerintah lokal ulai berinisiatif membangun infrastruktur dan fasilitas pariwisata dalam volume terbatas. 


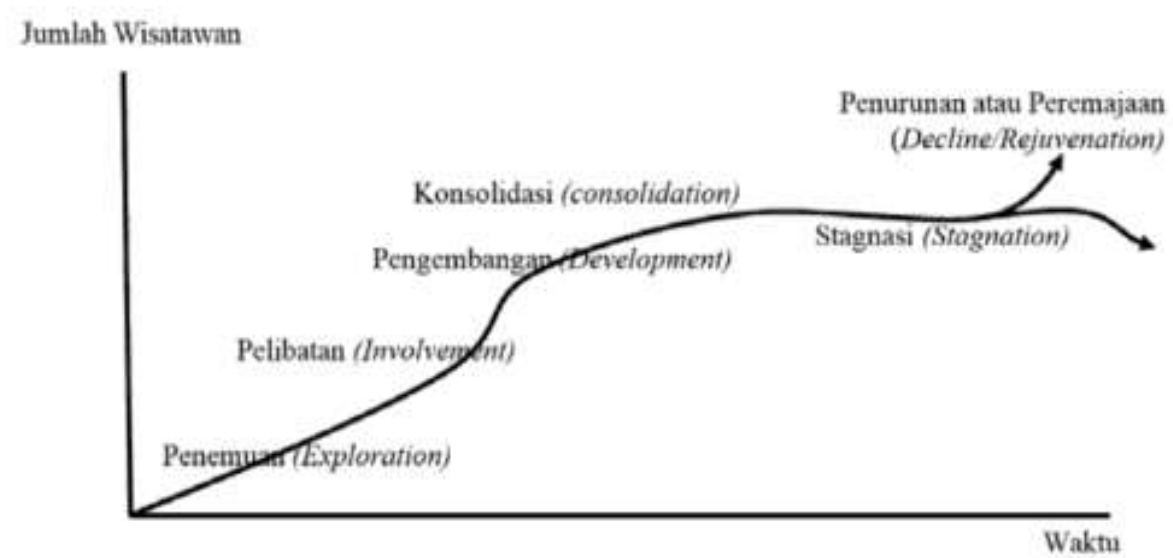

\section{Gambar 1. Butler's Tourist Area Life Cycle}

Sumber: Utama, 2017.

Tahap pengembangan merupakan siklus ketiga. Pada tahap ini, jumlah kunjungan wisatawan sudah mulai meningkat dan pihak pemerintah sudah mulai terbuka terhadap masuknya investor level nasional bahkan internasional, dan sudah mulai terbentuknya organisasi pariwisata yang berfungsi sebagai promotif.

Siklus keempat yaitu tahap konsolidasi, dimana sektor pariwisata mulai menunjukkan kontribusinya dalam struktur ekonomi daerah, dan semakin kuatnya jaringan internasional memegang peran terhadap kawasan wisata tersebut. Kondisi menyebabkan intervensi pemerintah lokal semakin menurun, sehingga perlu dilakukan upaya reorganisasi dan keseimbangan peran antara pihak pemerintah dan pihak swasta.

Pada tahap stagnasi sebagai siklus kelima, sudah terjadi peningkatan jumlah kunjungan wisatawan, namun hanya beberapa saat menunjukkan angka yang cenderung tetap. Untuk beberapa wisatawan meihat destinasi ini sudah mulai tidak menarik lagi bagi mereka, dan wisatawan yang datang adalah mereka yang masih setia. Pengelolaan objek wisata yang dinilai sangat berlebihan menciptakan dampak negatif bagi lingkungan objek wisata serta dampak sosial lainnya.
Siklus keenam adalah tahap penurunan atau peremajaan. Setelah terjadinya stagnasi, terdapat dua kemungkinan yang terjadi atas keberlanjutan destinasi wisata tersebut pada tahap ini. Jika pemanfaatan destinasi wisata tersebut tidak diubah, maka dapat dipastikan destinasi wisata akan ditinggalkan wisatawan.

Luturlean et al. (2019) berargumen pembangunan pariwisata harus memiliki tujuan, diantaranya dapat meningkatkan kualitas dan kuantitas destinasi pariwisata; dari segi pemasaran, destinasi pariwisata seharusnya dapat dikomunikasikan dan dipromosikan melalui media pemasaran yang efektif, efisien dan bertanggungjawab; menjadikan industri pariwisata yang mampu menggerakkan perekonomian; dan dalam pembangunan pariwisata perlu adanya sinergi antara kelembagaan kepariwisataan dan pengelola pariwisata secara profesional. Hal ini karena pada prinsipnya pembangunan pariwisata harus mampu memberi jaminan keberlanjutan, dapat memberikan keuntungan bagi masyarakat, dan tidak menimbulkan kerugian bagi generasi berikutnya.

\section{METODE PENELITIAN}

Objek dalam penelitian ini adalah wisata alam Pulau Rukui berlokasi di Kecamatan Banda Mulia, Kabupaten Aceh Tamiang. Data 
primer diperoleh langsung melalui observasi, wawancara, serta kuisioner yang diberikan kepada pengunjung (wisatawan) dan dinasdinas yang relevan yaitu BAPPEDA, dan Dinas Pariwisata, Pemuda dan Olahraga.

Populasi adalah para wisatawan yang berkunjung ke wisata alam Pulau Rukui. Teknik pengambilan sampel menggunakan accidental sampling, yaitu wisatawan yang secara kebetulan bertemu dengan peneliti dan dipandang orang tersebut benar-benar cocok dijadikan sebagai sumber data.

Dikarenakan jumlah populasi tidak diketahui pasti, maka penentuan jumlah sampel menggunakan unknown populations (Sugiyono, 2016). Derajat keyakinan sampel ditentukan pada 95\% maka diperoleh nilai $\mathrm{Z}$ sebesar 1,96; serta margin of error atau tingkat kesalahan yang dapat ditoleransi ditentukan sebesar $10 \%$. Menggunakan rumus tersebut maka diperoleh jumlah sampel penelitian ini sebanyak 100 responden.

Metode analisis data yang digunakan dalam penelitian ini adalah analisis SWOT yang selanjutnya dijabarkan sebagai elemenelemen Strength (kekuatan), Weakness (kelemahan), Opportunities (peluang), serta Threats (ancaman) (Rangkuti, 2017; Mustika \& Aditya, 2018, 2017), dengan gambaran matriks seperti tampak pada Tabel 3. Untuk mengetahui rating dari faktor internal dan faktor eksternal, digunakan kuesioner yang disebarkan pada wisatawan yang berkunjung ke wisata alam Pulau Rukui. Skala yang digunakan pada tiap item kuesioner memiliki rentang dari skor 1 yaitu skor yang menunjukkan kualitas paling rendah, sampai skor 4 yang menunjukkan kualitas paling tinggi.

Untuk menentukan kriteria skor yang termasuk dalam faktor kekuatan, kelemahan, peluang dan ancaman, maka dapat dicari panjang kelas interval terlebih dahulu. Dengan menggunakan Skor Tertinggi $\left(X_{t}\right)$ adalah 4 , serta Skor Terendah $\left(X_{r}\right)$ adalah 1, maka perhitungan Panjang Kelas Interval $(\mathrm{P})$ :

$$
\mathrm{P}=\frac{X_{t}-X_{r}}{X_{t}}=\frac{4-1}{4}=0,75
$$

Dengan menggunakan panjang kelas interval sebesar 0,75 dan skor terendah 1, maka bisa ditentukan rentang kriteria seperti terlihat dalam Tabel 4.

\section{HASIL ANALISIS \\ Faktor Kekuatan}

Berdasarkan Tabel 5 diketahui kelima indikator kekuatan rata-rata objek wisata Pulau Rukui adalah 3,13 termasuk kategori tinggi. Indikator "Pulau Rukui merupakan objek wisata yang menarik dan alami" menepati kategori sangat tinggi dengan skor 3,05. Selanjutnya indikator "suasana pantai Pulau Rukui memberi kenyamanan” memilik kategori tinggi dengan skor 2,86.

Tabel 3. Matriks SWOT

\begin{tabular}{|c|c|c|}
\hline EFAS & $\begin{array}{l}\text { STRENGTHS }(\mathrm{S}) \\
\text { Tentukan faktor-faktor } \\
\text { kelemahan internal }\end{array}$ & $\begin{array}{l}\text { WEAKNESSES }(\mathrm{W}) \\
\text { Tentukan faktor-faktor } \\
\text { kekuatan internal }\end{array}$ \\
\hline OPPORTUNITIES (O) & STRATEGI SO & STRATEGI WO \\
\hline $\begin{array}{l}\text { Tentukan faktor } \\
\text { peluang eksternal }\end{array}$ & $\begin{array}{c}\text { Ciptakan strategi yang menggunakan } \\
\text { kekuatan untuk memanfaatkan } \\
\text { peluang }\end{array}$ & $\begin{array}{c}\text { Ciptakan strategi yang meminimalkan } \\
\text { kelemahan untuk memanfaatkan } \\
\text { peluang }\end{array}$ \\
\hline THREATS (T) & STRATEGI ST & STRATEGI WT \\
\hline $\begin{array}{l}\text { Tentukan faktor } \\
\text { ancaman eksternal }\end{array}$ & $\begin{array}{l}\text { Ciptakan strategi yang menggunakan } \\
\text { kekuatan untuk mengatasi ancaman }\end{array}$ & $\begin{array}{c}\text { Ciptakan strategi yang meminimalkan } \\
\text { kelemahan untuk menghindari } \\
\text { ancaman }\end{array}$ \\
\hline
\end{tabular}

Sumber: Rangkuti, 2017. 
Tabel 4. Kriteria Kekuatan, Kelemahan, Peluang dan Ancaman

\begin{tabular}{ccc}
\hline No & Interval & Kriteria \\
\hline 1 & $3,26-4,00$ & Sangat Tinggi \\
2 & $2,51-3,25$ & Tinggi \\
3 & $1,76-2,50$ & Rendah \\
4 & $1,00-1,75$ & Sangat Rendah \\
\hline
\end{tabular}

Sumber: Diolah penulis, 2020.

Tabel 5. Skor Mean Kekuatan Objek Wisata Pulau Rukui

\begin{tabular}{clcc}
\hline No & \multicolumn{1}{c}{ Indikator Kekuatan } & Skor Mean & Keterangan \\
\hline 1 & $\begin{array}{l}\text { Pulau Rukui merupakan objek wisata yang menarik dan } \\
\text { alami }\end{array}$ & 3,09 & Sangat Tinggi \\
2 & $\begin{array}{l}\text { Suasana yang memberikan kenyamanan } \\
\text { Objek wisata Pulau Rukui layak dijadikan kawasan wisata } \\
\text { unggulan di Kecamatan Banda Mulia Kabupaten Aceh }\end{array}$ & 2,86 & Tinggi \\
\hline $\begin{array}{l}\text { Tamiang } \\
\text { Merupakan kawasan strategis dari fungsi dan daya dukung } \\
\text { lingkungan } \\
5\end{array}$ & $\begin{array}{l}\text { Masyarakat mendukung pemerintah untuk mengembang- } \\
\text { kan objek wisata Pulau Rukui }\end{array}$ & Sangat Tinggi \\
\hline & Mean & $\mathbf{3 , 1 3}$ & Tinggi \\
\hline
\end{tabular}

Sumber: Data primer (diolah), 2020.

Tabel 6. Skor Mean Kelemahan Objek Wisata Pulau Rukui

\begin{tabular}{clcc}
\hline No & \multicolumn{1}{c}{ Indikator Kelemahan } & Skor Mean & Keterangan \\
\hline 1 & $\begin{array}{l}\text { Pengembangan objek wisata Pulau Rukui yang dilakukan } \\
\text { pemerintah belum maksimal }\end{array}$ & 3,17 & Tinggi \\
2 & $\begin{array}{l}\text { Kurangnya promosi untuk menarik pengunjung ke objek } \\
\text { wisata Pulau Rukui }\end{array}$ & 3,13 & Tinggi \\
3 & $\begin{array}{l}\text { Sarana dan prasarana yang belum memadai (buruknya } \\
\text { akses jalan dan tidak ada transportasi khusus menuju objek } \\
\text { wisata) }\end{array}$ & 3,38 & Sangat Tinggi \\
4 & $\begin{array}{l}\text { Fasilitas belum tersedia (toilet umum dan pondok-pondok } \\
\text { untuk bersantai) }\end{array}$ & 3,55 & Sangat Tinggi \\
& Kebersihan pantai Pulau Rukui belum terjaga & 3,34 & Sangat Tinggi \\
\hline & Mean & $\mathbf{3 , 3 1}$ & Sangat Tinggi \\
\hline
\end{tabular}

Sumber: Data primer (diolah), 2020.

Kategori lainnya yang tergolong sangat tinggi adalah "objek wisata Pulau Rukui layak dijadikan kawasan wisata unggulan di Kecamatan Banda Mulia Kabupaten Aceh Tamiang" dengan skor 3,37. Selanjutnya, indikator "objek wisata Pulau Rukui merupakan kawasan strategis dari fungsi dan daya dukung lingkungan" memiliki kategori tinggi dengan skor 2,89. Indikator "masyarakat mendukung pemerintah untuk mengembangkan objek wisata Pulau Rukui" dalam tingkatan sangat tinggi dengan skor 3,45.

\section{Faktor Kelemahan}

Berdasarkan Tabel 6, nilai rata-rata tertinggi dari faktor kelemahan dalam upaya 
pengembangan objek wisata Pulau Rukui adalah 3,31. Masing-masing indikator ini memiliki nilai berbeda, seperti "pengembangan objek wisata Pulau Rukui yang dilakukan pemerintah masih belum secara maksimal" dengan nilai rata-rata 3,17 termasuk dalam kategori tinggi.

Kelemahan lainnya yang menghambat pengembangan objek wisata Pulau Rukui adalah "kurangnya promosi untuk menarik pengunjung ke objek wisata Pulau Rukui" dengan nilai rata-rata 3,13 termasuk kategori tinggi. Indikator "sarana dan prasarana yang belum memadai (buruknya akses jalan dan tidak ada transportasi khusus menuju objek)" memiliki rata-rata 3,38 adalah termasuk kategori sangat tinggi. Indikator terakhir yaitu "fasilitas belum tersedia (toilet umum dan pondok-pondok untuk bersantai)" mempunyai rata-rata 3,55 termasuk kategori sangat tinggi.

\section{Faktor Peluang}

Berdasarkan hasil olah data penelitian mengenai faktor peluang yang tampak pada Tabel 7 diperoleh nilai rata-rata untuk semua faktor peluang sebesar 3,28 dalam tingkatan sangat tinggi. Indikator "dengan adanya objek wisata Pulau Rukui mampu mendorong aktivitas ekonomi dan menciptakan lapangan kerja bagi masyarakat sekitar" masuk kategori sangat tinggi dengan nilai rata-rata 3,37. Indikator "adanya kesempatan untuk dapat menggaet investor untuk berinvestasi dengan adanya pengembangan objek wisata Pulau Rukui” memiliki rata-rata 3,18 dalam kategori tinggi. Selanjutnya, indikator peluang dengan kategori sangat tinggi adalah "banyaknya wisatawan yang ingin berkunjung ke objek wisata Pulau Rukui” dengan skor 3,31. Indikator peluang terakhir adalah "keinginan masyarakat sekitar untuk terlibat secara langsung dalam pengembangan objek wisata Pulau Rukui" dengan skor 3,27 dalam kategori sangat tinggi.

\section{Faktor Ancaman}

Berdasarkan hasil olah data pada Tabel 8 dijelaskan bahwa rata-rata faktor ancaman dari semua indikator sebesar 3,19 dalam tingkatan tinggi. Indikator "adanya persaingan objek wisata lain yang akses jalannya lebih bagus dan dekat dengan kota" memiliki skor 2,97 berada pada kategori tinggi. Indikator ancaman lainnya yaitu "kurangnya kesadaran wisatawan untuk menjaga objek wisata Pulau Rukui” memiliki skor 3,26 dengan kategori sangat tinggi. Indikator terakhir yaitu "terjadinya pedagang musiman disekitar objek wisata Pulau Rukui" memiliki nilai rata-rata 3,36 dalam kategori sangat tinggi.

\section{Tabel 7. Skor Mean Peluang Objek Wisata Pulau Rukui}

\begin{tabular}{clcc}
\hline No & \multicolumn{1}{c}{ Indikator Peluang } & Skor Mean & Keterangan \\
\hline 1 & $\begin{array}{l}\text { Dengan adanya objek wisata Pulau Rukui mampu } \\
\text { mendorong aktivitas ekonomi dan menciptakan lapangan } \\
\text { kerja bagi masyarakat sekitar }\end{array}$ & 3,37 & Sangat Tinggi \\
2 & $\begin{array}{l}\text { Adanya kesempatan untuk dapat menggaet investor untuk } \\
\text { berinvestasi dengan adanya pengembangan objek wisata }\end{array}$ & 3,18 & Tinggi \\
\hline $\begin{array}{l}\text { Pulau Rukui } \\
\text { Banyaknya wisatawan yang ingin berkunjung ke objek } \\
\text { wisata Pulau Rukui }\end{array}$ & 3,31 & Sangat Tinggi \\
\hline $\begin{array}{l}\text { Keinginan masyarakat sekitar untuk terlibat secara } \\
\text { langsung dalam pengembangan objek wisata Pulau Rukui }\end{array}$ & 3,27 & Sangat Tinggi \\
\hline & \multicolumn{1}{c|}{ Mean } & Sangat Tinggi \\
\hline
\end{tabular}

Sumber: Data primer (diolah), 2020. 
Tabel 8. Skor Mean Ancaman Objek Wisata Pulau Rukui

\begin{tabular}{clcc}
\hline No & \multicolumn{1}{c}{ Indikator Ancaman } & Skor Mean & Keterangan \\
\hline 1 & $\begin{array}{l}\text { Adanya persaingan objek wisata lain yang akses jalannya } \\
\text { lebih bagus dan dekat dengan kota }\end{array}$ & 2,97 & Tinggi \\
2 & $\begin{array}{l}\text { Kurangnya kesadaran wisatawan untuk menjaga objek } \\
\text { wisata Pulau Rukui }\end{array}$ & 3,26 & Sangat Tinggi \\
3 & $\begin{array}{l}\text { Terjadinya pedagang musiman di sekitar objek wisata } \\
\text { Pulau Rukui }\end{array}$ & 3,36 & Sangat Tinggi \\
\hline & Mean & $\mathbf{3 , 1 9}$ & Tinggi \\
\hline
\end{tabular}

Sumber: Data primer (diolah), 2020.

Tabel 9. Faktor Strategis Internal Objek Wisata Pulau Rukui

\begin{tabular}{|c|c|c|c|}
\hline Faktor Strategis Internal & Bobot & Rating & Skor \\
\hline \multicolumn{4}{|l|}{ Kekuatan } \\
\hline$\sqrt{ }$ Pulau Rukui merupakan objek wisata yang menarik dan alami & 0,0976 & 3 & 0,2928 \\
\hline$\sqrt{ }$ Suasana yang memberikan kenyamanan & 0,0990 & 4 & 0,3960 \\
\hline $\begin{array}{l}\sqrt{ } \text { Objek wisata Pulau Rukui layak dijadikan kawasan wisata } \\
\text { unggulan di Kecamatan Banda Mulia Kab. Aceh Tamiang }\end{array}$ & 0,0987 & 4 & 0,3948 \\
\hline$\sqrt{ }$ Merupakan kawasan strategis dari fungsi dan daya dukungan & 0,0968 & 3 & 0,2904 \\
\hline $\begin{array}{l}\sqrt{ } \text { Masyarakat mendukung pemerintah untuk mengembangkan } \\
\text { objek wisata Pulau Rukui }\end{array}$ & 0,1007 & 4 & 0,4028 \\
\hline \multicolumn{2}{|l|}{ Jumlah Skor Kekuatan } & & 1,7768 \\
\hline \multicolumn{4}{|l|}{ Kelemahan } \\
\hline $\begin{array}{l}\sqrt{ } \text { Pengembangan objek wisata Pulau Rukui yang dilakukan } \\
\text { pemerintah masih belum maksimal }\end{array}$ & 0,1004 & 4 & 0,4016 \\
\hline $\begin{array}{l}\sqrt{ } \text { Kurangnya promosi untuk menarik pengunjung ke objek } \\
\text { wisata Pulau Rukui }\end{array}$ & 0,1010 & 4 & 0,4040 \\
\hline $\begin{array}{l}\sqrt{ } \text { Sarana dan prasarana yang belum memadai (buruknya akses } \\
\text { jalan dan tidak ada trasportasi khusus menuju objek wisata }\end{array}$ & 0,1021 & 4 & 0,4084 \\
\hline $\begin{array}{l}\sqrt{ } \text { Fasilitas belum tersedia (toilet umum dan pondok-pondok } \\
\text { untuk bersantai) }\end{array}$ & 0,1027 & 4 & 0,4108 \\
\hline$\sqrt{ }$ Kebersihan pantai Pulau Rukui belum terjaga & 0,1010 & 4 & 0,4040 \\
\hline \multicolumn{2}{|l|}{ Jumlah Skor Kelemahan } & & 2,0288 \\
\hline Jumlah Skor Keseluruhan & 1 & & 3,8056 \\
\hline
\end{tabular}

Sumber: Data primer (diolah), 2020.

Berdasarkan Tabel 9 serta Tabel 10 diperoleh bobot serta rating faktor strategis internal dan eksternal objek wisata Pulau Rukui dimana pembobotan dilakukan dengan tujuan bahwa faktor-faktor tersebut dapat memberikan dampak terhadap faktor strategis. Pembobotan dalam faktor-faktor strategis objek wisata Pulau Rukui diperoleh dari bobot $=m_{x} / m_{t}$, dimana $m_{x}$ yaitu nilai mean dari faktor $\mathrm{X}$, dan $m_{t}$ yaitu nilai mean total faktor strategis internal. Sementara itu, tujuan rating adalah memberikan skala mulai dari 4 sampai 1 berdasarkan pengaruh faktor itu terhadap pengembangan objek wisata Pulau Rukui, dan memperoleh skor pembobotan untuk memperoleh skor pembobotan objek wisata Pulau Rukui. Nilai total ini menunjukkan bagaimana objek wisata Pulau Rukui bereaksi terhadap faktor-faktor strategis internalnya. 
Tabel 10. Faktor Strategis Eksternal Objek Wisata Pulau Rukui

\begin{tabular}{|c|c|c|c|}
\hline Faktor Strategis Eksternal & Bobot & Rating & Skor \\
\hline \multicolumn{4}{|l|}{ Peluang } \\
\hline $\begin{array}{l}\sqrt{ } \text { Dengan adanya objek wisata Pulau Rukui mampu mendorong } \\
\text { aktivitas ekonomi dan menciptakan lapangan kerja bagi } \\
\text { masyarakat sekitar }\end{array}$ & 0,1465 & 3 & 0,4395 \\
\hline $\begin{array}{l}\sqrt{ } \text { Adanya kesempatan untuk dapat menggaet investor untuk } \\
\text { berinvestasi dengan adanya pengembangan objek wisata Pulau } \\
\text { Rukui }\end{array}$ & 0,1453 & 3 & 0,4359 \\
\hline $\begin{array}{l}\sqrt{ } \text { Banyaknya wisatawan yang ingin berkunjung ke objek wisata } \\
\text { Pulau Rukui }\end{array}$ & 0,1465 & 3 & 0,4395 \\
\hline $\begin{array}{l}\sqrt{ } \text { Keinginan masyarakat sekitar untuk terlibat secara langsung } \\
\text { dalam pengembangan objek wisata Pulau Rukui }\end{array}$ & 0,1427 & 3 & 0,4281 \\
\hline Jumlah Skor Kekuatan & & & 1,7430 \\
\hline \multicolumn{4}{|l|}{ Ancaman } \\
\hline $\begin{array}{l}\sqrt{ } \text { Adanya persaingan objek wisata lain yang akses jalannya } \\
\text { lebih bagus dan dekat dengan kota }\end{array}$ & 0,1415 & 3 & 0,4245 \\
\hline $\begin{array}{l}\sqrt{ } \text { Kurangnya kesadaran wisatawan untuk menjaga objek wisata } \\
\text { Pulau Rukui }\end{array}$ & 0,1427 & 3 & 0,4281 \\
\hline $\begin{array}{l}\sqrt{ } \text { Terjadinya pedagang musiman disekitar objek wisata Pulau } \\
\text { Rukui }\end{array}$ & 0,1347 & 3 & 0,4041 \\
\hline Jumlah Skor Kelemahan & & & 1,2567 \\
\hline Jumlah Skor Keseluruhan & 1 & & 2,9997 \\
\hline
\end{tabular}

Sumber: Data primer (diolah), 2020.

Tabel 11. Rekapitulasi Hasil Perhitungan Analisis SWOT

\begin{tabular}{ccc}
\hline No. & \multicolumn{1}{c}{ Uraian } & Nilai \\
\hline \multirow{2}{*}{1} & Faktor Internal & \\
& $\bullet$ Kekuatan & 1,78 \\
& - Kelemahan & 2.02 \\
\hline \multirow{2}{*}{2} & Faktor Eksternal & \\
& • Peluang & 1,74 \\
& - Ancaman & 1,26 \\
\hline
\end{tabular}

Sumber: Data primer (diolah), 2020.

Berdasarkan perhitungan menggunakan analisis SWOT, maka didapatkan nilai akhir dari kekuatan, kelemahan, peluang dan ancaman seperti terangkum dalam Tabel 11, dimana:

$>$ Kekuatan - kelemahan (faktor internal) :

$$
=1,78-2,02=\mathbf{- 0 , 2 4}
$$

Peluang - ancaman (faktor eksternal) : $=1,74-1,26=\mathbf{0 , 4 8}$
Apabila nilai-nilai tersebut dimasukkan dalam Matrix Grand Strategy maka terlihat posisi pengembangan sektor pariwisata di objek wisata Pulau Rukui berada di posisi Strategi Turn-around. Gambar 2 menjelaskan bahwa posisi objek wisata Pulau Rukui berada di Kuadran III. Strategi yang dapat diterapkan dalam situasi seperti ini adalah strategi Turn-around yaitu strategi yang meminimalkan kelemahan dengan berupaya memanfaatkan peluang yang ada. 


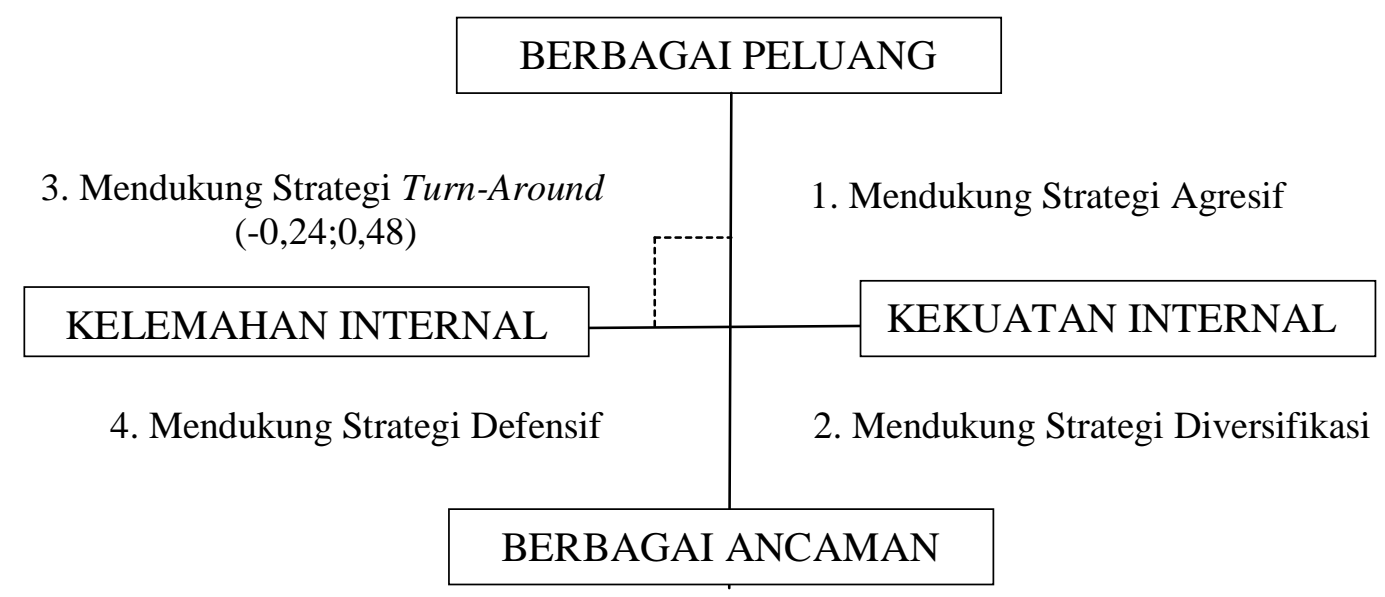

\section{Gambar 2. Matrix Grand Strategy Objek Wisata Pulau Rukui}

Sumber: Diolah penulis, 2020.

\section{Pembahasan}

Berdasarkan hasil penelitian diperoleh pengembangan objek wisata alam Pulau Rukui memiliki potensi untuk dikembangkan dalam rangka menarik minat wisatawan berkunjung, sehingga hal ini dapat menjadi sumber pendapatan bagi daerah, di Kabupaten Aceh Tamiang. Salah satu cara penting untuk mengembangkan industri pariwisata di kawasan ini adalah dengan mengidentifikasi lebih banyak area wisata ini dan mengukur kelayakan wilayah dalam hal kekuatan untuk menarik pengunjung (Khayyati \& Nourani, 2014; Rikah \& Muniroh, 2017).

Dalam penelitian yang dilakukan Wong et al. (1998) menyatakan pengembangan pariwisata pesisir secara terencana maupun tidak terencana akan terus berdampak negatif terhadap lingkungan pesisir, sehingga perlu adanya analisis mengenai dampaknya atas lingkungan, pengelolaan peningkatan jumlah wisatawan, upaya evaluasi pengembangan pariwisata, pertimbangan aspek konservasi, pendefinisian dan revisi standar perencanaan dan tujuan pembangunan berkelanjutan. Di sisi lain, semakin meningkatnya jumlah wisatawan yang berkunjung maka akan dapat meningkatkan pendapatan daerah melalui retribusi dari objek wisata tersebut.
Sejalan dengan penelitian sebelumnya, peran pemerintah daerah dan investor terkait belum maksimal untuk pengembangan dan pengelolaan wisata Pulau Rukui (Sihasale et. al., 2013). Pemerintah juga dapat membentuk suatu organisasi yang dapat mempromosikan keragaman geografis sehingga terdapat pengetahuan baru yang mengarah pada inovasi untuk menghindari adanya "lock-in effect" (Brandão et al., 2019). Oleh karena itu, perencanaan pariwisata haruslah menyeluruh, fleksibel, adaptif dan transparan dan harus memperhitungkan aspek: (1) daya dukung pariwisata; (2) penilaian dampak lingkungan dari pengembangan pariwisata; (3) prinsipprinsip pengelolaan zona pesisir terintegrari yang diadopsi untuk area-area tertentu; (4) pendekatan pemasaran yang baru dan efektif; serta, (5) proses perencanaan strategis "step-by-step" (Khotimah et al., 2017; Mustika \& Aditya, 2018).

Untuk itu, pembangunan infrastruktur industri pariwisata harus mempertahankan karakter unik dan daya tarik tujuan wisata, membatasi kapasitas jumlah wisatawan, mengadopsi kegiatan inovatif yang baru dan menarik untuk membantu pengembangan pariwisata, seperti promosi warisan bahari, wisata bawah laut dan arkeologi pesisir (Papageorgiou, 2019; Utama, 2017). 


\section{Faktor Pendukung}

Faktor pendukung yang teridentifikasi bagi pengembangan objek wisata Pulau Rukui dalam penelitian ini adalah sebagai berikut.

Pertama, Pulau Rukui merupakan objek wisata yang menarik dan alami dimana memiliki keindahan alam yang masih sangat alami sehingga menarik untuk dikunjungi. Pantai ini memiliki tekstur pasir yang sangat lembut, ombak pantai yang tenang dapat dimanfaatkan wisatawan untuk berenang bersama keluarga, serta objek ini dapat dijadikan destinasi wisata.

Kedua, Pantai Pulau Rukui memiliki suasana yang memberikan kenyamanan dimana ketika memasuki kawasan ini kita disuguhkan dengan pemandangan hamparan pantai yang sangat luas, pinggiran pantai yang dikelilingi pohon bakau yang membuat mata tak bosan. Angin yang berhembus kencang menambah kenyamanan ketika berkunjung ke objek wisata ini.

Faktor pendukung ketiga bahwa objek wisata Pulau Rukui layak dijadikan kawasan wisata unggulan di Kecamatan Banda Mulia Kabupaten Aceh Tamiang dimana keindahan alam yang masih alami menjadikan objek wisata ini disukai oleh wisatawan karena memberikan kenyamanan. Ketika masuk ke kawasan objek wisata maka kita akan disuguhkan pemandangan pantai yang indah, dengan hembusan angin yang membuat nyaman sehingga menjadikan objek wisata Pulau Rukui menjadi salah satu objek wisata unggulan di Kecamatan Banda Mulia Kabupaten Aceh Tamiang.

Keempat, objek wisata alam Pulau Rukui merupakan kawasan strategis dari segi fungsi dan daya dukung lingkungan. Lokasi objek wisata Pulau Rukui sangat strategis sehingga pengunjung dapat dengan mudah untuk datang ke objek wisata ini, dan objek wisata ini memiliki fungsi melindungi kelestarian lingkungan hidup.
Faktor pendukung kelima yang dapat diidentifikasi adalah masyarakat mendukung pemerintah untuk mengembangkan objek wisata Pulau Rukui. Dengan dilakukan pengembangan maka akan semakin banyak wisatawan untuk berkunjung sehingga membuka peluang kerja dan mendorong aktivitas ekonomi untuk masyarakat sekitar.

\section{Faktor Penghambat}

Beberapa faktor penghambat dalam pengembangan objek wisata alam Pulau Rukui yang teridentifikasi melalui penelitian ini adalah sebagai berikut.

Faktor penghambat pertama bahwa pengembangan objek wisata alam Pulau Rukui yang dilakukan pemerintah dinilai masih belum maksimal. Karenanya diharapkan Dinas Priwisata dan Pemerintah Daerah untuk melakukan pengembangan terhadap objek wisata ini menjadi lebih baik lagi agar mampu meningkatkan jumlah pengunjung.

Kedua, kurangnya upaya promosi untuk menarik pengunjung ke objek wisata Pulau Rukui. Promosi yang dijalankan oleh pihak kepariwisataan Kabupaten Aceh Tamiang masih belum ada, sehingga masyarakat mengetahui objek wisata Pulau Rukui masih sebatas dari mulut ke mulut.

Ketiga, sarana dan prasarana yang belum memadai (buruknya akses jalan dan tidak ada transportasi khusus menuju objek wisata). Perjalanan menuju objek wisata Pulau Rukui tidak didukung dengan kondisi jalan yang baik, dimana dilihat dari kondisi jalan bebatuan yang dapat membahayakan pengunjung. Selain itu, terdapat jembatan penghubung yang tidak bisa dilewati oleh kendaraan roda empat. Untuk itu, perlu dilakukan perbaikan dan pelebaran jalan. Belum adanya akses transportasi umum menuju objek wisata alam Pulau Rukui. 
Keempat, fasilitas dinilai belum tersedia dengan baik, seperti toilet umum dan pondokpondok untuk bersantai. Toilet merupakan fasilitas yang sangat penting. Selama ini, pengunjung hanya bisa menggunakan toilet darurat yang hanya ditutupi selembar terpal. Jadi sangat menyulitkan pengunjung untuk keperluan buang air. Selain itu, air bersih belum tersedia di objek wisata ini. Pondokpondok untuk tempat bersantai juga sangat diperlukan demi upaya membuat nyaman pengunjung.

Faktor penghambat terakhir adalah aspek kebersihan pantai Pulau Rukui belum terjaga. Masih banyak terdapat sampah yang berserakan di bibir pantai Pulau Rukui baik berupa sampah organik maupun non organik. Selain itu, potongan pohon-pohon tembakau berserakan dimana-mana, dimana hal ini dapat membahayakan pengunjung apalagi yang membawa anak-anak.

\section{Strategi Pengembangan Objek Wisata Pulau Rukui}

Berdasarkan hasil analisis SWOT yang telah dilakukan, objek wisata Pulau Rukui dinilai berada dalam Kuadran III pada diagram SWOT. Opsi yang digunakan yaitu strategi WO (Weaknesses and Opportunities), dengan mempertimbangkan bahwa objek wisata Pulau Rukui mempunyai potensi yang menarik dan alami tetapi tidak didukung dengan promosi yang menarik serta sarana dan prasarana yang belum memadai. Untuk itu, dalam mengembangkan objek wisata Pulau Rukui harus berupaya menciptakan strategi dengan meminimalkan kelemahan (weaknesses) serta memanfaatkan peluang (opportunities) yang ada.

Dengan demikian, opsi-opsi kebijakan pengembangan objek wisata Pulau Rukui yang ditawarkan adalah sebagai berikut.

Pertama, berupaya meningkatkan aksi promosi mengenai objek wisata Pulau Rukui melalui berbagai media baik cetak maupun elektronik, serta pameran-pameran wisata yang dilakukan Dinas Pariwisata, Pemuda dan Olahraga Kabupaten Aceh Tamiang.

Kedua, meningkatkan fasilitas sarana dan prasarana serta infrastuktur penunjang seperti membangunan wahana permainan air, kereta wisata dan fasilitas-fasilitas penunjang lainnya, sehingga menarik dan memberikan kenyamanan bagi pengunjung. Selain itu, perbaikan jalan yang rusak dan menyediakan transportasi khusus menuju objek wisata Pulau Rukui dapat memudahkan akses bagi pengunjung. Dalam hal ini, pemerintah dapat bekerjasama dengan investor swasta.

Ketiga, pengembangan objek wisata Pulau Rukui yang dilakukan pemerintah belum maksimal, untuk itu perlu ditingkatkan karena semakin bertambahnya objek-objek wisata lain dan bertambahnya persaingan antar objek wisata. Karenanya, objek wisata Pulau Rukui memerlukan inovasi baru untuk berkembang yang lebih baik. Jika pemerintah daerah dalam pengembangan objek wisata Pulau Rukui terkendala oleh dana, maka perlu bantuan dari investor swasta.

Keempat, pemerintah dapat bekerjasama dengan masyarakat sekitar berpartisipasi dalam pengembangan objek wisata Pulau Rukui dengan memberikan sosialisasi dan pembinaan sehingga dapat meningkatkan kualitas SDM dalam mengelola objek wisata Pulau Rukui. Dengan adanya tenaga kerja professional dapat menjaga kebersihan pantai maka dapat dilakukan usaha mengurangi kerusakan lingkungan.

\section{SIMPULAN}

Obyejk wisata Pulau Rukui dinilai berada di Kuadran III dalam Matrix Grand Strategy. Strategi yang dapat digunakan dalam situasi seperti ini yaitu strategi Turnaround, berupa meminimalkan kelemahan 
dengan memanfaatkan peluang yang ada yang terdapat di wisata alam tersebut.

Strategi yang dapat dilakukan adalah dengan meningkatkan promosi terhadap objek wisata Pulau Rukui melalui surat kabar maupun teknologi informasi, serta melalui even-even yang diadakan oleh Pemerintah Daerah Kabupaten Aceh Tamiang. Strategi lainnya yang dapat dilakukan yaitu upaya meningkatkan fasilitas sarana dan prasarana, infrastruktur serta menyediakan transportasi khusus menuju objek wisata, sehingga dapat memudahkan akses bagi wisatawan yang ingin berkunjung.

Objek wisata Pulau Rukui juga dinilai membutuhkan bentuk-bentuk inovasi baru agar dapat berkembang menjadi lebih baik. Pemerintah daerah dapat bekerjasama dengan investor swasta. Pemerintah juga dapat bekerjasama dengan masyarakat sekitar dengan memberikan kegiatan sosialisasi dan pembinaan sehingga dapat meningkatkan kualitas SDM (sumber daya manusia) dalam mengelola objek wisata Pulau Rukui. Dengan adanya tenaga kerja professional maka dapat menjaga aspek kebersihan pantai sehingga mengurangi kerusakan lingkungan.

\section{REFERENSI}

Badan Pusat Statistik. (2019). Data objek wisata di Kabupaten Aceh Tamiang. BPS Kabupaten Aceh Tamiang.

Bahiyah, C., Riyanto, W. H., \& Sudarti, S. (2018). Strategi Pengembangan Potensi Pariwisata di Pantai Duta Kabupaten Probolinggo. Jurnal Ilmu Ekonomi, 2(1), 95-103. Retrieved from http:// 202.52.52.22/index.php/jie/article/view/ 6970.

Brandão, F., Breda, Z., \& Costa, C. (2019). Innovation and internationalization as development strategies for coastal tourism destinations: The role of organizational networks. Journal of Hospitality and Tourism Management, 41(December), 219-230. doi: 10.1016/ j.jhtm.2019.10.004.

Dinas Pariwisata, Pemuda dan Olahraga Kabupaten Aceh Tamiang. (2020). Daftar kunjungan wisatawan ke objek wisata Pulau Rukui Kabupaten Aceh Tamiang tahun 2019. Dinas Pariwisata, Pemuda dan Olahraga Kabupaten Aceh Tamiang.

Khayyati, E., \& Nourani, S. (2014). Strategic planning for tourism development using S.W.O.T model - Case study: Borjlou tourist village in Ardebil. MAGNT Research Report, 2(6), 12-21. Retrieved from http://brisjast.com/wp-content/ uploads/2015/06/Nov-2-2014.pdf.

Khotimah, K., Wilopo \& Hakim, L. (2017). Strategi pengembangan destinasi pariwisata budaya (Studi kasus pada kawasan Situs Trowulan sebagai pariwisata budaya unggulan di Kabupaten Mojokerto). Jurnal Administrasi Bisnis (JAB), 41(1), 5665. Retrieved from: http://administrasi bisnis.studentjournal.ub.ac.id/index.php /jab/article/view/1657.

Latuconsina, O. C. H., Syaukat, Y., \& Siregar, H. (2013). Strategi pembiayaan terhadap pengembangan pariwisata berbasis masyarakat di Kota Ambon. Jurnal Manajemen Pembangunan Daerah, 5(2), 62-75. doi: 10.29244/ jurnal_mpd.v5i2.24640.

Luturlean, B. S., Sukmadi, Kalsum, E. R. U., Maulina, L., \& Arifin, D. (2019). Strategi bisnis pariwisata. Humaniora.

Mustika, A., \& Aditya, M. K. (2018). SWOT analysis of rural tourism development: Case study of Kampung Tajur, Purwakarta. Advances in Economics, Business and Management Research (AEBMR), 52(2), 19-28. doi: 10.2991/ ICTGTD-18.2018.3.

Papageorgiou, A. N. (2019). Developing a Sufficient and Effective Coastal Tourism Model. TOLEHO: Journal of Tourism, Leisure and Hospitality, 1(1), 29-34. Retrieved from https:// dergipark.org.tr/tr/download/articlefile/812488. 
Pradana, G. Y. K. (2019). Sosiologi pariwisata. STPBI PRESS.

Rangkuti, F. (2017). Teknik membedah kasus bisnis analisis SWOT: Cara menghitung bobot, rating dan OCAI. PT. Gramedia Pustaka Utama.

Rikah, Tahwin, M., \& Muniroh, H. (2017). Strategi perencanaan dan pengembangan industri pariwisata dengan menggunakan metode analisis SWOT (Studi kasus objek wisata Dampo Awang Beach Kabupaten Rembang). Fokus Ekonomi, 12(1), 1-18. doi: 10.34152/fe.12.1.1-18.

Sihasale, D. A., Hakim, L., Suharyanto, A., \& Soemarno. (2013). The strategy of potential tourism development in Namalatu Beach at Nusaniwe sub district, Ambon City, Indonesia. Research Inventy: Internasional Journal of Engineering and Science, 3(1), 39-45. Retrieved from http:// www.researchinventy.com/v3i1.html.

Sugiyono. (2016). Metode penelitian kuantitatif, kualitatif dan $R \& D$. CV. Alfabeta.

Utama, I. G. B. R. (2017). Pemasaran pariwisata. ANDI.

Wong, P. P. (1998). Coastal tourism development in Southeast Asia: Relevance and lessons for coastal zone management. Ocean \& Coastal Management, 38(2), 89-109. doi: 10.1016/S0964-5691(97)00066-5.

Zebua, M. (2016). Inspirasi pengembangan pariwisata daerah. Deepublish. 